\title{
Risk Management, Rational Herding and Institutional Investors: A Macro View
}

\author{
Torben Lütje, University of Hannover \\ Lukas Menkhoff, University of Hannover*
}

Discussion paper No. 285

October 2003

ISSN 0949-9962

\begin{abstract}
As institutional investors are engaged to realize attractive risk-adjusted returns, they can by definition be seen as risk managers. This paper analyzes their risk management behavior from a macro perspective and focuses on their incentives for rational herding. Based on a questionnaire survey we find clear evidence of herding among fund managers in Germany. While all different subgroups of fund managers perceive institutional herding, senior fund managers perceive herding even more strongly than more junior managers. Regarding herding as rational strategy of adapting to incentives, one might ascribe this finding to the higher pressure of success that senior managers face.
\end{abstract}

JEL classification: G 14, G 23

Keywords: Institutional investors, herd behavior, momentum strategy

* Corresponding author.

Department of Economics, University of Hannover, Königsworther Platz 1, 30167 Hannover, Germany, menkhoff@gif.uni-hannover.de 


\section{Introduction}

One of the most significant changes in our financial system in the past decades has been the rise of institutional investors. Institutional investors, such as fund managers, insurance companies and others, have become the dominant players in international financial markets. The information they use is the most relevant, their opinions are those which are not only driving the markets, but also increasingly driving overall economies. Since one of the main tasks of institutional investors is to achieve attractive risk-adjusted returns, they can be seen as risk managers. However, this micro perspective does not necessarily match a macro point of view. The macro perspective considers the economy-wide risk-related consequences of the typical behavior of institutional investors as a group. We argue that both perspectives of risk - the micro versus the macro - differ, since the risk-adverse behavior of the single institutional investor does not necessarily minimize risks for the overall economy.

The debate on the international financial architecture is a debate on the efficiency of markets and their organization. Essentially, however, it is a debate on risk control (Eichengreen 1999, Frenkel and Menkhoff 2000). The downside risks of international financial markets have become obvious in the series of financial crises during the 1990s. Some of these crises were clearly related to the behavior of institutional investors, most obvious in the LTCM case (in 1998), which is a good example of the self account speculation of leading financial institutions. Others, such as the Scandinavian banking crisis (in the early 1990s) or the banking scandal in Berlin (in 2001), also involved the same top management that is responsible for institutional investments. Finally, even the emerging market crises in far away places may have been influenced by industrialized countries' advanced institutional investors and not just by the less developed local financial institutions (see e.g. Radelet and Sachs 1998). So risk management is a serious concern not only for micro management but also on the macro scale of financial markets. This applies not only to banks but also to institutional investors.

In some sense, however, institutional investors may not be the primary group when analyzing risky aspects of international financial markets. Institutional investors 
are professionals who understand the risks of financial markets as well as the instruments used to cover these risks. On a macro level, one can even argue that institutionals provide a major benefit to our economies through their (international) diversification of portfolios. It is therefore not institutional investors as a whole that impels our analysis; it is rather a certain aspect of their behavior which is based on their incentive structure that raises concerns. In short, the theoretically demonstrated and also empirically proven herd behavior is at the root of the analysis here. The paper analyzes the relevance of this herd behavior and its implications for macroeconomic risk management. There is a lack of knowledge in the literature regarding whether herding is seen by institutional investors themselves and whether this phenomenon is possibly related to certain persons within the group of institutional investors only. Thus, an important part of our line of argument is the presentation of respective findings from a recent questionnaire survey. Finally, we want to emphasize that this analysis does not present a balanced discussion on the overall benefits and costs of institutional investors but intends to highlight a narrow - although relevant - issue.

The remainder of this paper proceeds in the following manner: in Section 2 we start with a short review of the incentives influencing the decision making of institutional investors. Section 3 selectively surveys empirical literature on herding before we present our own findings from a questionnaire survey conducted with fund managers in Germany in Section 4. Finally, Section 5 draws some conclusions about the management of macro risks.

\section{Incentives towards rational herding of institutional investors}

The incentives for institutional investors can usefully be derived within a principal-agent-framework. Institutional investors manage funds (as agents) that belong to private or corporate clients (who can be considered principals). To make the agents act with optimum effort, as desired by their principals, their investment performance is typically measured in relation to a benchmark or a peer group (see e.g. Lakonishok et al. 1992). Consequently, institutional investors are interested in what the other market participants do. The relevant question here is, how strong is this interest in the real world? Are institutional investors so interested in their competitors' invest- 
ment decisions that they base their own decisions on imitation instead of their own fundamental information?

In this vein, Scharfstein and Stein (1990) develop a widely cited model in which institutional investors rationally ignore the fundamental information they possess and imitate the investment decisions of other managers. This socially inefficient behavior can be rational from the manager's personal perspective (see also Devenow and Welch 1996, and Calvo and Mendoza 2000). The core assumption in this respect is the idea that an unprofitable investment decision has significantly less negative impact on his/her reputation in the labor market when others make the same mistake as well. Scharfstein and Stein call this incentive to herd the "sharing-the-blame" effect, i.e. herding institutional investors share the blame of being wrong with the others of the herd if there are systematically unpredictable shocks. This view draws from Keynes' (1936, p. 158) argumentation that "it is better for reputation to fail conventionally than to succeed unconventionally". Unprofitable investment decisions that deviate from the majority of the peer group's decisions can indeed have substantial impact on a manager's career. Khorana (1996) documents a negative correlation between fund performance and managerial replacement. Accordingly, he ascribes the tendency of herding to the risk of being replaced if an asset manager performs worse than the peer group. Chevalier and Ellison (1999) supplement that this negative correlation is even more characteristic for younger asset managers. Maug and Naik (1995), who develop optimal remuneration contracts for asset managers, show that such contracts induce herding in order to reduce deviations from the benchmark.

After an institutional investor has made his/her investment decision, the labor market updates its assessment of the institutional investor's capabilities: ex post it becomes obvious whether the investment decision was profitable or not, as well as whether the decision maker acted in accordance with the others or contrary to them (Scharfstein and Stein 1990, p. 466). While Scharfstein and Stein concentrate on conditionally correlated signals of smart managers as a requirement for reputational herding, Ottaviani and Sørensen (2000) show that the correlation reinforces reputational herding, albeit it is not a necessary condition. The herding of asset managers assumes that all of these decision makers received the same information and acted accordingly. By following the herd, an institutional investor can make his/her clients 
believe that he/she has received the same information as the others - even if he/she has not.

It seems plausible that the more often the labor market updates its assessments of the managers' capabilities, the more interested these managers become in their reputation within the market (see also Holmström 1999). Regarding the professional asset management business, clients generally demand an account of their investments' performance at short regular intervals, so that the performance of asset managers is typically evaluated every three months on average (Arnswald 2001, p. 24, and Lakonishok et al. 1991, p. 227). As a result, we conclude that asset managers have a strong incentive to rationally herd in their investment decisions. Empirical research, however, has to overcome objections to test this theoretically derived hypothesis.

\section{Evidence on herding of fund managers}

A basic problem of empirical work in this field is rooted in the fact that there are several kinds of herd behavior. Bikhchandani and Sharma (2001) distinguish "spurious" herding form "intentional" herding. The first occurs when market players who face similar problems and information sets make the same decisions. This kind of behavior is from a macroeconomic point of view of course not problematic at all. Intentional herding, on the other hand, is conscious behavior that can be attributed to several factors. First, concerning imperfect information in markets, information-based herding occurs when market participants deliberately copy the investment decision of others, because they suppose the others have received some relevant news (e.g. information about an investment's return). A second reason for intentional herding can be the individual's inherent preference for conformity. Finally, asset managers face incentives for reputational herding due to their typical compensation scheme. Figure 1 illustrates the different types of herding.

INSERT FIGURE 1 ABOUT HERE. 
The three distinct types of intentional herding are related to each other and for our purposes do not need to be differentiated. Information-based herding is a type of behavior geared to rely on others', instead of one's own information. Even if one's own information is limited, this behavior is no contribution towards efficient markets, as it can at best imitate better informed competitors with a time lag. Under unfortunate circumstances, there are only seemingly better informed opinion leaders that shape the investment decisions. The second type of intentional herding, conformitymotivated, makes, as its name implies, no contribution towards efficient markets. It is thus reputation-based herding that has the strongest rational appeal and may be regarded as the primary motivation of intentional herding among professional asset managers. It provides a plausible explanation of apparently stable and robust herding (Hirshleifer and Teoh 2003, p. 56).

Unfortunately, it is difficult to discriminate spurious from intentional herding. Empirical studies often measure conspicuously correlated trading activities (synchronous buying or selling) of particular securities as a proxy for intentional herding (Lakonishok et al. 1992a). But even though herding undoubtedly leads to correlated trading, the reverse is not necessarily true (Bikhchandani and Sharma 2001, p. 293). Correlated trading is thus a necessary but not sufficient condition for the existence of intentional herding. Keeping this limitation in mind, Lakonishok et al. (1992a), Grinblatt et al. (1995), and Wermers (1999) find little evidence for institutional herding by testing correlated trading activities within quarterly portfolio holdings (related Borensztein and Gelos 2003). Sias (2002) takes a different approach by directly measuring to what extent traders mimic each other over adjacent quarters. Consequently, he documents strong evidence of institutional herding (particularly information-based herding). Hwang and Salmon (2003) develop another new measure of herding based on a cross-sectional variance of the individual asset betas and find significant evidence of herding towards the market portfolio, i.e. they observe decreasing beta factors. Interestingly, and in contrast to general opinion, they find stronger herding in quiet rather than hectic markets. Moreover, Oehler and Chao (2000) find strong evidence of market-wide herding in the German bond market, although it is weaker than in stock markets (however, they find no excess herding regarding single securities). Oehler and Chao explain the difference between the mar- 
kets with the higher diversity in the bond segment, i.e. differences in nominal interest rates, quality, maturity and issuer.

This somewhat inconclusive evidence motivates us to pursue another method in examining possible intentional herding. We ask market participants by questionnaire, to what extent they perceive (intentional) herding within financial markets. A questionnaire survey is an established method to learn about personal views and behavior. Earlier papers such as Shiller (1989), Blinder (2000) or Strong and Xu (2003) also apply this method to analyze financial markets.

\section{Survey findings on herd behavior}

This section presents findings from a questionnaire survey that was conducted with fund managers in Germany in 2002. Between August and December 2002, all fund management companies in Germany were repeatedly contacted in order to participate in a survey on behavioral finance in investment management. In total, we received 117 completed questionnaires from stock and bond managers. As the survey was conducted by mail as well as by email, we cannot report a response rate on the full survey - regarding those companies that received mailed questionnaires only, the response rate is approximately 30-40\% (see Brozynski et al. 2003 for more details). The participation rate of fund management companies is $59 \%$.

\subsection{Evidence of herding among institutional investors}

In the questionnaire we ask fund managers to assess the following statement: [A] "Herding is also observable amongst professional asset managers." It should be noted that the term "herding" here refers strictly to intentional herding, and that the participants were aware of this, as we concluded from previous interviews. The spectrum of possible answers to the statement ranges from 1 ("completely agree") to 6 ("completely disagree"). The questionnaire survey provides clear proof that asset managers believe in herd behavior in professional financial markets: from the 116 participants who answer this question, 109 (94\%) respond positively ("completely agree", "strongly agree" and "somewhat agree", respectively), indicating their percep- 
tion of institutional herding. The mean answer (2.02) as well as the median answer (2) is "strongly agree". For more details see Table 1.

Just as Oehler and Chao (2000) document different degrees of herding in the German bond markets and stock markets, we also analyze the perception of herd behavior in stock markets and bond markets separately. With respect to Oehler and Chao's results, we expect a stronger perception of institutional herding in stock markets than in bond markets. When correlating asset managers' assessments of statement $[\mathrm{A}]$ with their major investment segment, we indeed come to the conclusion that equity fund managers perceive more institutional herding than asset managers who handle bond funds, although the difference is not statistically significant. The first mentioned agree to statement $[A]$ with a mean answer of 1.95 , while the mean answer of the latter is 2.14. Our survey results thus tend to conform with Oehler and Chao's finding (see the upper part of Table 1).

\section{INSERT TABLE 1 ABOUT HERE.}

Beyond the finding of perceived herd behavior in financial markets, we are also interested in whether intentional herding could be motivated by the sharing-the-blame effect (see Scharfstein and Stein 1990). Therefore, we ask the asset managers to assess the subsequent statement with the same spectrum of possible answers (1-6) as described above: [B] "The discussion of an investment decision with colleagues reduces the pressure of being successful." We are aware that this statement does not fully grasp the idea of sharing-the-blame, i.e. reputation-based herding, but may be also seen as a question addressing conformity-based herding. Interesting enough, almost half of the respondents tend to agree with statement [B]. However, contradiction is stronger than approval, as the mean answer (3.73) as well as the median answer (4) show. Finally, bond managers reject the statement less than stock managers, although the difference is not significant (see the lower part of Table 1). How should these findings be interpreted? 
We remember from the personal interviews that fund managers hesitate to subscribe to statement $[\mathrm{B}]$ as it could indicate a weakness to come to an independent decision. Moreover, discussion with colleagues is only a very imperfect insurance against performance pressure from clients. These factors possibly dampen agreement with statement $[B]$. Nevertheless, it is another correlation which supports the sharing-the-blame effect as a relevant element of herding. Responses show a significant positive correlation between the perception of herding and the assessment that the discussion with colleagues lowers the pressure of being successful (see bottom of Table 1).

\subsection{Relation between the perception of herding and the institutional investors' characteristics}

We have so far seen that the perception of herding is very wide-spread and may plausibly be linked to rational motives. In another exercise aimed at achieving a better understanding of the correlates of herding we question which certain subgroups of fund managers perceive herding in professional financial markets most. We expect that more experienced, better educated and more senior asset managers possess a better understanding of influences on decision making at financial markets. Do they perceive more herding?

To test these hypotheses we relate the asset managers' perception of herding (statement $[A]$ ) with their personal characteristics. First, when relating the asset managers' assessment of statement $[\mathrm{A}]$ with their professional experience we find that more experienced asset managers (practical experience $>15$ years) agree with statement $[\mathrm{A}]$ with a mean answer of 1.85 , while relatively low experienced asset managers (practical experience $<5$ years) see less herding in financial markets (mean answer only 2.36). These findings also hold for age as another proxy for experience (see Table 2). It seems that fund managers become aware of the herding phenomenon over time.

INSERT TABLE 2 ABOUT HERE. 
On the other hand, when the educational level of the asset managers is taken as a factor, the result is that asset managers of lower educational levels perceive more herding than their graduated colleagues. In fact, while graduated asset managers give a mean answer of 2.08 , asset managers who did not study at all agree to statement $[A]$ with a mean answer of 1.65. On the basis of our data we cannot decide whether better educated managers correctly recognize less herding than others or whether they falsely attribute the behavior to other factors.

To conclude, we examine the relation of the asset managers' assessment of statement $[A]$ with their current position within their company. While asset managers in senior positions give a mean answer of 1.74 , asset managers of lower hierarchical levels agree to statement $[A]$ with a mean answer of only 2.23 .

In order to learn more about the relations of interest we perform rank correlations between the personal characteristics discussed and the perception of herding. Table 3 gives the coefficients of correlation which support the above found relations.

\section{INSERT TABLE 3 ABOUT HERE.}

Moreover, it is only the positive correlation between being in a senior position and perceiving herd behavior in the markets that is statistically significant. This finding may be ascribed to the higher pressure of success that senior managers face. It is interesting in this respect that senior managers generally acknowledge that discussions with colleagues reduce the pressure to be successful, as $57.9 \%$ of them agree (answer categories 1-3) with statement [B] (not reported in a table).

In summary, the perception of herding is basically established in all groups of the market (independent of experience, age or education). The only marked exceptions are senior fund managers, who perceive herding even more strongly than more junior managers. If we regard herding as a rational (intentional) strategy of adapting 
to incentives (see also Menkhoff 2002), senior managers seem to be under stronger pressure and thus possibly support the perception of herding more.

\subsection{Perception of herding and the sources of information}

As a final exercise aimed at a better understanding of the background of herding, it is asked whether the perception of herding is related to a preference for certain sources of information. It can be speculated that herding in the markets might lead to deviations from fundamentally determined prices. It may be seen as a consequence of this perception that fund managers anticipate this influence and possibly do not rely solely on fundamental analysis as an analytical tool. For evidence in foreign exchange markets see Menkhoff (1998).

Hence, we ask the recipients of our questionnaire to describe the importance of different types of information for their investment decisions. The spectrum of possible answers ranges from 1 ("highest relevance") to 6 ("no relevance"). Our survey results show that asset managers generally attach most importance to fundamental information (mean answer 1.82). Technical analysis and discussions with colleagues are less important (mean answer 3.03 and 3.18, respectively), whereas investment decisions of other market participants play a minor role for their own decision making (mean answer 3.73). For more details see Table 4.

\section{INSERT TABLE 4 ABOUT HERE.}

Next, do asset managers who see more herd behavior base their investment decisions on other types of information than their colleagues who perceive less herding? As Figure 2 illustrates, we find a negative correlation between asset managers' perceptions of institutional herding and their use of fundamental analysis (please notice the inverse scale of the left $y$-axis). Asset managers who perceive the strongest herding (answer category 1) attach only medium importance to the use of fundamentals (mean answer 2.09), while this type of information is more important (mean an- 
swer 1.53) to asset managers who observe less herding (answer category 3). The dashed line represents the resulting linear regression. The solid line, representing the number of responses, illustrates that asset managers who generally see less institutional herding (answer categories 4-6) merely represent an almost negligible small group (only $6 \%$ of total). Table 4 also shows the negative correlation between the perception of herding and the importance of fundamentals for own investment decisions, albeit it is not statistically significant.

\section{INSERT FIGURE 2 ABOUT HERE.}

Furthermore, the survey provides significant evidence that asset managers who perceive more herding attach more importance to technical analysis. This result is not surprising, because the use of technical analysis rests upon the opinion that financial prices follow trends, and the latter can be triggered by the herding of market participants. Consistent with this fact, they typically are momentum traders who consider shorter investment horizons (see Table 4; see also Brozynski et al. 2003). This finding is also plausible, because the momentum strategy seems to be profitable within short and medium term investment periods up to 12 months (Jegadeesh and Titman 1993, 2001) and its success can also be attributed to herd behavior in financial markets (see e.g. Nofsinger and Sias 1999).

Moreover, we find a significant negative correlation between the perception of herding and the importance of discussion with colleagues as a source of information for own investment decisions. This finding may be unexpected, as the sharing-theblame effect addressed by statement $[\mathrm{B}]$ above involves discussion with colleagues (see Section 4.1). One might speculate that asset managers who perceive more herd behavior do not regard the opinion of their colleagues as a primary source of information (which technical analysis is) but as a source of confirmation. 


\section{Consequences for the management of macro risks}

There is much debate about strong incentives towards herding among professional fund managers. The empirical evidence for this is hampered by the fact that herding is not easy to identify. Consequently, the evidence has so far been weak, although recent studies seem to provide support for the herding hypothesis. We see our survey as an instrument to complement earlier approaches. Asking fund managers whether they observe herding among their peer group gives a very strong finding: herding exists. Moreover, the sharing-the-blame effect is related to the perception of herding which may be regarded as an additional indication for rational intentional herding.

Further correlations of the perception of herding with personal characteristics support the view that herding is not a phenomenon of a certain subgroup. By contrast, herding is recognized by all groups. The importance of herding is highlighted by the fact that senior managers regard it even more strongly than others. Finally, we find herding is related to the amount of attention, namely less, given to fundamental analysis. This last point is of particular importance for our overall theme, i.e. consideration of macro risks, as it may lead to an increasing inherent instability in the markets.

The survey findings are intended to be a contribution to what practitioners and officials often allude to: the increasing importance of institutional investors may have ambiguous effects on the macroeconomic functioning of financial markets (Menkhoff 2002). This could have far reaching implications, as stated for example by Chari and Kehoe (2003, p. 25): "we think, therefore, that models of herd behavior have the potential to help us understand financial crises in emerging markets and elsewhere." What would be an appropriate policy reaction under these circumstances?

The underlying problem - the divergence of micro and macro risks - reminds of the similar logical structure in the regulation of banks. Bank managers have "suboptimal" incentives due to principal-agent-problems. Bank regulation is economically warranted and addresses the micro incentives. However, explicit macro aspects are 
neglected and have in part become worse due to the focus on controlling the micro risks. The debate on macro-prudential regulation of banks is still in its infancy stages and there are no fully convincing and practically experienced solutions yet (see e.g. Borio 2003).

This excursus on banking regulation indicates three lessons: first, increasing the micro efficiency of institutions and the financial system does not automatically increase functionality in a macroeconomic sense (see Shiller 2003). There is, secondly, some market discipline at work which helps to keep the system going even without any explicit regulation of the above discussed issues. Finally, this demands a careful search for any possible improvements in policy making, as regulations tend to produce their own distortions.

So we come up with a very modest conclusion. Recent studies hint at an interesting problem - rational herding of institutional investors may produce macro risks which seems to be worthy of more research efforts.

\section{References}

Arnswald, Torsten (2001) Investment Behaviour of German Equity Fund Managers, An Exploratory Analysis of Survey Data. Deutsche Bundesbank Discussion Paper 08/01, Frankfurt

Bikhchandani, Sushil and Sunil Sharma (2001), Herd Behavior in Financial Markets: A Review. IMF Staff Papers 47(3):279-310

Blinder, Alan S. (2000), Central Bank Credibility: Why Do We Care? How Do We Build It?. American Economic Review 90(5):1421-1431

Borensztein, Eduardo R. and R. Gaston Gelos (2003), A Panic-Prone Pack? The Behavior of Emerging Market Mutual Funds. IMF Staff Papers 50(1):43-63

Borio, Claudio (2003), Towards a Macroprudential Framework for Financial Supervision and Regulation?. CESifo Economic Studies 49(2):181-215 
Brozynski, Torsten, Lukas Menkhoff and Ulrich Schmidt (2003), The Use of Momentum, Contrarian and Buy-\&-Hold Strategies: Survey Evidence from Fund Managers. Working Paper, University of Hannover

Calvo, Guillermo A. and Enrique G. Mendoza (2000), Rational Contagion and the Globalization of Securities Markets. Journal of International Economics 51(1):79113

Chari, V.V. and Patrick J. Kehoe (2003), Financial Crises as Herds: Overturning the Critiques. NBER Working Paper 9658, April

Chevalier, Judith and Glenn Ellison (1999) Career Concerns of Mutual Fund Managers. Quarterly Journal of Economics 114:389-432

Devenow, Andrea and Ivo Welch (1996), Rational Herding in Financial Economics, European Economic Review 40:603-615

Eichengreen, Barry (1999), Toward a New International Financial Architecture, A Practical Post-Asia Agenda. Institute for International Economics, Washington, D.C.

Frenkel, Michael and Lukas Menkhoff (2000), Stabile Weltfinanzen? Die Debatte um eine neue internationale Finanzarchitektur. Springer, Berlin et al.

Grinblatt, Mark, Sheridan Titman and Russ Wermer (1995), Momentum Investment Strategies, Portfolio Performance, and Herding: A Study of Mutual Fund Behavior, American Economic Review 85(5):1088-1105

Hirshleifer, David and Siew Hong Teoh (2003), Herd Behaviour and Cascading in Capital Markets: a Review and Synthesis. European Financial Management $9(1): 25-66$

Holmström, Bengt (1999), Managerial Incentive Problems: A Dynamic Perspective. Review Economic Studies 66(1):169-182

Hwang, Soosung and Mark Salmon (2003), Market Stress and Herding. Working Paper, Sir John Cass Business School, City University London

Jegadeesh, Narasimhan and Sheridan Titman (1993), Returns to Buying Winners and Selling Losers: Implications for Stock Market Efficiency. Journal of Finance 48(1):65-91

Jegadeesh, Narasimhan and Sheridan Titman (2001), Profitability of Momentum Strategies: An Evaluation of Alternative Explanations. Journal of Finance 56(2):699-720

Keynes, John Maynard (1936), The General Theory of Employment, Interest and Money. MacMillan, London

Khorana, Ajay (1996), Top Management Turnover. An Empirical Investigation of Mutual Fund Managers. Journal of Financial Economics 40:403-427 
Lakonishok, Josef, Andrei Shleifer, Richard H. Thaler and Robert W. Vishny (1991), Window Dressing By Pension Fund Managers. American Economic Review, Papers and Proceedings 81:227-231

Lakonishok, Josef, Andrei Shleifer, Richard H. Thaler and Robert W. Vishny (1992), The Structure and Performance of the Money Management Industry. Brookings Papers on Economic Activity, Microeconomics, 339-391

Lakonishok, Josef, Andrei Shleifer, Robert W. Vishny (1992a), The Impact of Institutional Trading on Stock Prices. Journal of Financial Economics: 32, 23-43

Maug, Ernst and Narayan Naik (1995), Herding and Delegated Portfolio Management: The Impact of Relative Performace Evaluation on Asset Allocation. Working Paper, London Business School

Menkhoff, Lukas (1998), The Noise Trading Approach - Questionnaire Evidence from Foreign Exchange. Journal of International Money and Finance 17:547-564

Menkhoff, Lukas (2002), Institutional Investors: The External Costs of a Successful Innovation. Journal of Economic Issues 36(4):907-933

Nofsinger, John R. and Richard W. Sias (1999), Herding and Feedback Trading by Institutional and Individual Investors, Journal of Finance 54(6):2263-2295

Oehler, Andreas and George Goeth-Chi Chao (2000), Institutional Herding in Bond Markets. Working Paper, Bamberg University

Ottaviani, Marco and Peter Sørensen (2000), Herd Behavior and Investment: Comment. American Economic Review 90(3):695-704

Radelet, Steven and Jeffrey D. Sachs (1998), The East Asian Financial Crisis: Diagnosis, Remedies, Prospects. Brookings Papers on Economic Activity 1:1-90

Scharfstein, David S. and Jeremy C. Stein (1990), Herd Behavior and Investment. American Economic Review 80(3):465-479

Shiller, Robert J. (1989): Market Volatility. MIT Press, Cambridge, Mass.

Shiller, Robert J. (2003), From Efficient Markets Theory to Behavioral Finance. Journal of Economic Perspectives 17(1):83-104

Sias, Richard W. (2002), Institutional Herding. Forthcoming in Review of Financial Studies

Strong, Norman and Xinzhong Xu (2003), Understanding the Equity Home Bias: Evidence from Survey Data. Review of Economics and Statistics 85(2):307-312

Wermers, Russ (1999), Mutual Fund Herding and the Impact on Stock Prices. Journal of Finance 54:581-622 
Figure 1. Different types of herding

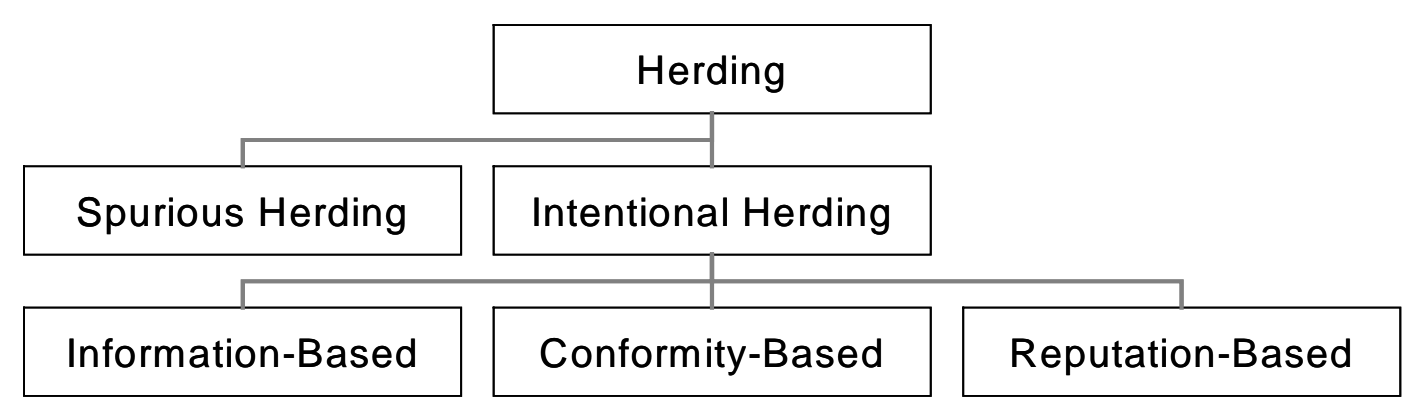


Table 1. Evidence of herding among institutional investors (Part 1)
Statement $[\mathrm{A}]$ "Herding is also observable amongst professional asset managers." 6 answering categories from "completely agree" (coded as 1) to "completely disagree" (coded as 6).

\begin{tabular}{|c|c|c|c|}
\hline Agreement with statement $[\mathrm{A}]$ & $\begin{array}{l}\text { All fund } \\
\text { managers }\end{array}$ & $\begin{array}{l}\text { Equity fund } \\
\text { managers }\end{array}$ & $\begin{array}{l}\text { Bond fund } \\
\text { managers }\end{array}$ \\
\hline (1) Completely agree & $30.2 \%$ & $31.1 \%$ & $30.6 \%$ \\
\hline (2) Strongly agree & $49.1 \%$ & $50.0 \%$ & $47.7 \%$ \\
\hline (3) Somewhat agree & $14.7 \%$ & $14.9 \%$ & $11.1 \%$ \\
\hline (4) Somewhat disagree & $1.7 \%$ & $1.4 \%$ & $2.8 \%$ \\
\hline (5) Strongly disagree & $3.4 \%$ & $2.7 \%$ & $5.6 \%$ \\
\hline (6) Completely disagree & $0.9 \%$ & $0.0 \%$ & $2.8 \%$ \\
\hline Number & 116 & 74 & 36 \\
\hline Mean answer & 2.02 & 1.95 & 2.14 \\
\hline Median answer & 2 & 2 & 2 \\
\hline $\begin{array}{l}\text { No difference }{ }^{1)} \text { between equity } \\
\text { and bond fund managers }\end{array}$ & $\begin{array}{l}-0.370 \\
(0.712)\end{array}$ & & \\
\hline
\end{tabular}

Evidence of herding among institutional investors (Part 2)

Statement $[\mathrm{B}] \quad$ "The discussion of an investment decision with colleagues reduces the pressure of being successful." 6 answering categories from "completely agree" (coded as 1) to "completely disagree" (coded as 6).

\begin{tabular}{lccc}
\hline Agreement with statement $[\bar{B}]$ & $\begin{array}{c}\text { All fund } \\
\text { managers }\end{array}$ & $\begin{array}{c}\text { Equity fund } \\
\text { managers }\end{array}$ & $\begin{array}{c}\text { Bond fund } \\
\text { managers } \\
13.9 \%\end{array}$ \\
(1) Completely agree & $6.9 \%$ & $4.1 \%$ & $11.1 \%$ \\
(2) Strongly agree & $16.4 \%$ & $17.6 \%$ & $36.1 \%$ \\
(3) Somewhat agree & $25.9 \%$ & $21.6 \%$ & $11 \%$ \\
(4) Somewhat disagree & $11.2 \%$ & $10.8 \%$ & $16 \%$ \\
(5) Strongly disagree & $26.7 \%$ & $31.1 \%$ & $11.1 \%$ \\
(6) Completely disagree & $12.9 \%$ & $14.9 \%$ & 36 \\
Number & 116 & 74 & 3.39 \\
Mean answer & 3.73 & 3.92 & 3 \\
Median answer & 4 & 4 & \\
No difference ${ }^{1)}$ between equity & -1.613 & & \\
and bond fund managers & $(0.107)$ & & \\
Rank correlation ${ }^{2)}$ between & $0.211^{* *}$ & & \\
agreement with statement & $(0.023)$ & & \\
[A] and [B] & & & \\
\hline
\end{tabular}

1) The table gives the z-value of the Mann-Whitney U-test and the p-value in parentheses.

2) The table gives the coefficient of the Spearman rank correlation and the $p$-value in parentheses. Asterisks refer to level of significance, ${ }^{\star}: 10$ per cent, ${ }^{\star *}: 5$ per cent. ${ }^{* \star \star}: 1$ per cent. 
Table 2. Perception of herding according to investors' characteristics

\begin{tabular}{|c|c|c|c|c|}
\hline $\begin{array}{ll}\text { Statement } & \text { "Her } \\
{[\mathrm{A}]} & \text { ans } \\
& \text { plet }\end{array}$ & $\begin{array}{l}\mathrm{ng} \text { is also obser } \\
\text { ring categories } \mathrm{f} \\
\text { disagree" (code }\end{array}$ & $\begin{array}{l}\text { le amongst profe } \\
\text { m "completely agr } \\
\text { as 6). }\end{array}$ & $\begin{array}{l}\text { onal asse } \\
\text { " (coded a }\end{array}$ & $\begin{array}{l}\text { lagers." } 6 \\
\text { to "com- }\end{array}$ \\
\hline Characteristics & & $\begin{array}{l}\text { Mean answer to } \\
\text { statement }[A]\end{array}$ & Number & $\begin{array}{l}\text { Standard } \\
\text { deviation }\end{array}$ \\
\hline Age & $<35$ years & 2.21 & 58 & 1.166 \\
\hline & $35-45$ years & 1.87 & 53 & 0.735 \\
\hline & $>45$ years & 1.67 & 3 & 0.577 \\
\hline Professional & $<5$ years & 2.36 & 25 & 1.254 \\
\hline experience & $5-15$ years & 1.99 & 67 & 0.945 \\
\hline & $>15$ years & 1.85 & 20 & 0.671 \\
\hline Education & Academic & 2.08 & 95 & 1.038 \\
\hline & Non-academic & 1.65 & 17 & 0.606 \\
\hline Occupational & Senior & 1.74 & 38 & 0.724 \\
\hline position & Junior & 2.23 & 65 & 1.115 \\
\hline
\end{tabular}

Table 3. Rank correlation on the perception of herding and personal characteristics

\begin{tabular}{lcccc}
\hline & Higher & More prof. & Higher & Senior \\
& age & experience & education & position \\
Stronger perception & 0.129 & 0.119 & -0.152 & $0.231^{* *}$ \\
of herding & $(0.171)$ & $(0.210)$ & $(0.109)$ & $(0.019)$ \\
[Number] & {$[114]$} & {$[112]$} & {$[112]$} & {$[103]$} \\
\hline
\end{tabular}

The table gives the coefficient of the Spearman rank correlation and the $p$-value in parentheses. Asterisks refer to level of significance, ${ }^{*}: 10$ per cent, ${ }^{* *}: 5$ per cent. ${ }^{* *}: 1$ per cent. 
Table 4. Relations between the perceptions of herding and the importance of different sources of information

\begin{tabular}{|c|c|c|c|c|c|}
\hline $\begin{array}{l}\text { (Higher) Importance of } \\
\text { different sources } \\
\text { of information }\end{array}$ & $\begin{array}{l}\text { Funda- } \\
\text { mentals }\end{array}$ & $\begin{array}{c}\text { Technical } \\
\text { analysis }\end{array}$ & $\begin{array}{l}\text { Discussion } \\
\text { with } \\
\text { colleagues }\end{array}$ & $\begin{array}{l}\text { (Longer) } \\
\text { Investment } \\
\text { horizon }\end{array}$ & $\begin{array}{l}\text { Momentum } \\
\text { trader }\end{array}$ \\
\hline Mean answer & 1.82 & 3.03 & 3.18 & - & - \\
\hline $\begin{array}{l}\text { Rank correlation with } \\
\text { perception of herding }\end{array}$ & $\begin{array}{l}-0.141 \\
(0.132)\end{array}$ & $\begin{array}{l}0.182^{*} \\
(0.052)\end{array}$ & $\begin{array}{l}-0.237^{\star \star} \\
(0.011)\end{array}$ & $\begin{array}{l}-0.117 \\
(0.211)\end{array}$ & $\begin{array}{l}0.196^{\star *} \\
(0.043)\end{array}$ \\
\hline [Number] & {$[115]$} & {$[114]$} & [115] & [116] & [107] \\
\hline
\end{tabular}

1) The table gives the coefficient of the Spearman rank correlation and the p-value in parentheses. Note: "Investment decisions of other market participants" play a minor role as source of information for own decision making (mean answer 3.73). Its correlation with asset managers' perception of herding is far from being signifiçant and therefore not presented in the table. Asterisks refer to level of significance, ${ }^{\star}: 10$ per cent, ${ }^{\star \star}: 5$ per cent, ${ }^{\star \star \star}: 1$ per cent.

Figure 2. Relation between the perception of herding and the importance of fundamentals

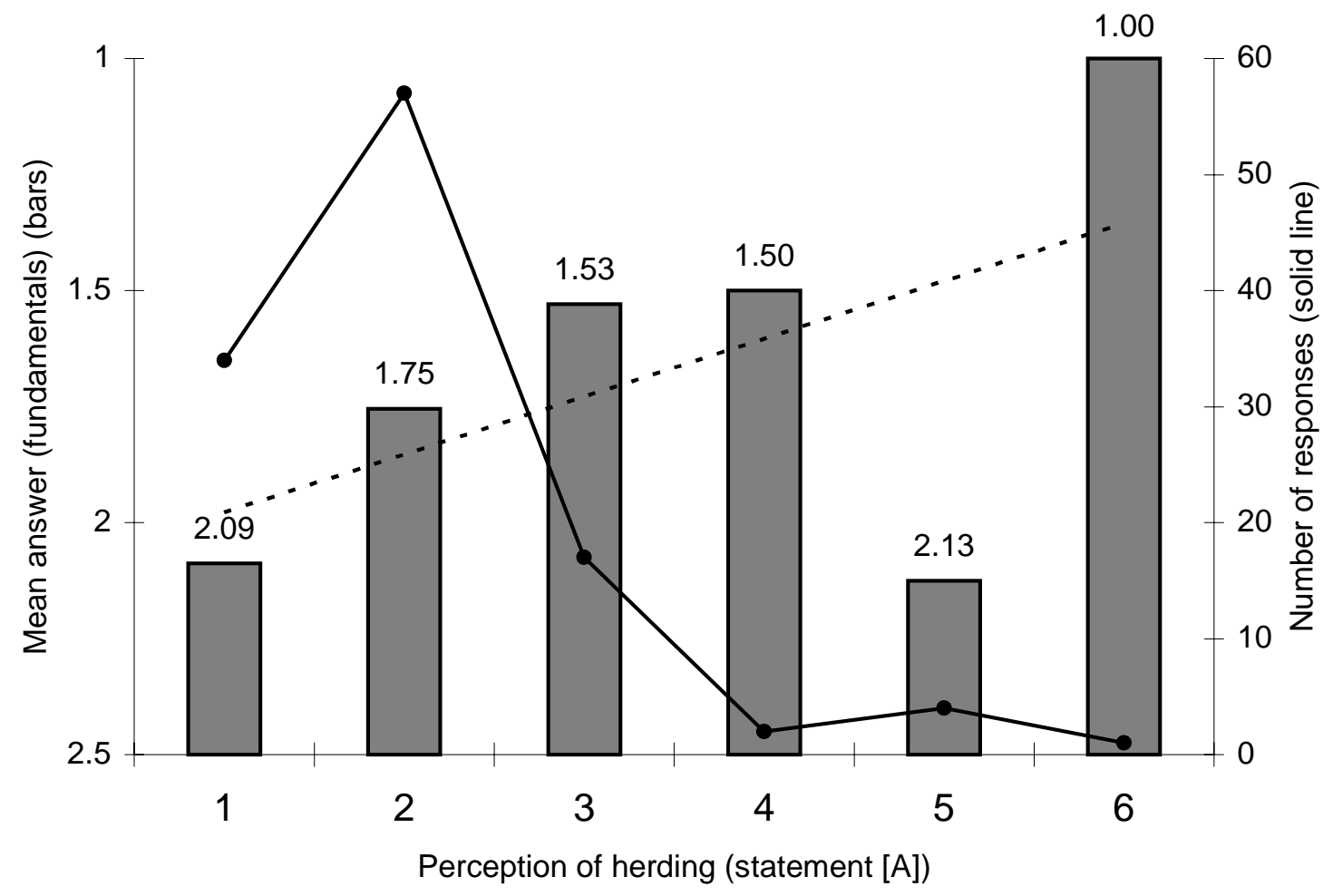

